\title{
DOES THE PRESENCE OF STRAW IN THE BILLET AFFECT THE QUALITY OF SUGARCANE PLANTING SYSTEMS?
}

\author{
Aycon T. L. Frazão ${ }^{1}$, Rafael H. de F. Noronha ${ }^{2 *}$, Carlos E. A. Furlani ${ }^{1}$ \\ ${ }^{2 *}$ Corresponding author. Federal University of Southern Bahia/ Itabuna - BA, Brazil. \\ E-mail: rafael.noronha.agro@gmail.com | ORCID ID: https://orcid.org/0000-0003-0205-9180
}

\author{
KEYWORDS \\ control letters, \\ distributor, primary \\ extractor.
}

\begin{abstract}
The mechanized harvesting process of sugarcane seedlings affects the mechanized planting operation in the sense that straw adhered to the billet can reduce the quantity of non-viable gems obtained as a result of mechanical damage sustained during the mechanized operation. This study proposes a method to improve the quality of the implantation of sugarcane crop by prevention of damages caused mainly during October/November, when adverse climatic conditions of higher water stresses and high temperatures exist. The objective of this study is to evaluate the quality of the sugarcane planting operation using seedlings with and without straw, distributed by planters and distributors of chopped sugarcane, and comparing their performance to that of semimechanized planting. The study was conducted at Fazenda Santa Clara, located in Pradópolis - São Paulo, Brazil and considered five processes: mechanized planting of seedlings without straw, mechanized planting of seedlings with straw, mechanized distribution of seedlings without straw, mechanized distribution of seedlings with straw, and semi-mechanized planting. Fifty sample points were used to collect data for each process, as per the principles of Statistical Process Control. The number of unfeasible gems and faults in the stand reduced with the presence of straw in the grinding wheel, in addition to less variability being presented. The presence of straw in the billet enabled the best overall quality of sugarcane plantation.
\end{abstract}

\section{INTRODUCTION}

Brazil stands out in the production of bioenergetic crops, particularly sugarcane, as the world's largest producer. São Paulo accounts for $52 \%$ of Brazil's sugarcane plantation and, consequently, is the largest state producer in the country (CONAB, 2017).

Cebim (2008) comparatively evaluated mechanized and semi-mechanized planting and observed that the mechanized sugarcane systems presented delayed sprouting, smaller averages of tillers per meter of furrow, and smaller numbers of viable gems. However, it was concluded that there was a $64.1 \%$ reduction in costs per hectare compared to the semi-mechanized system.

Many internal and external factors can hinder the quality and success of sugarcane planting. According to Garcia (2008), the internal factors linked to the potential of sugarcane plantations are billet size, energy reserve, gem age, and aridity. Casagrande (1991), Carlin et al. (2004), Ide et al. (1984), Marchiori et al. (2006), and Raveli (2013) consider the main external factors to be: planting depth, interspacing, mechanical damage to gems, southern cover, failure of seedling deposition, number of viable gems, and compaction post coverage.

The quality of agricultural processes can be managed by the aid of a statistical process control tool, as it is efficient in characterizing variability and can conduct an evaluation of operations (Suguisawa et al., 2007; Toledo et al., 2008). A good explanation for the term "quality" is the decrease in variability; thus, the lower the variability, the higher the reliability and approval of the product or service (Montgomery, 2016).

The objective of this study was to evaluate the operation quality of planting sugarcane seedlings with and without straw attached to the grinding wheel, using planters and distributors of chopped sugarcane, as compared to semi-mechanized planting. It was assumed that straw retained in the billet can reduce the number of unviable gems obtained due to mechanical damage, and the gems could be protected from adverse weather conditions, thus reducing failures in the planting stand.

\footnotetext{
${ }^{1}$ State University Paulista/ Jaboticabal - SP, Brazil. 


\section{MATERIAL AND METHODS}

\section{Experimental Characterization}

The study was conducted at Santa Clara Farm, in Pradópolis - São Paulo, in November 2017. The coordinates for the experimental area are $21^{\circ} 16^{\prime} 35^{\prime \prime} \mathrm{S}$, $48^{\circ} 06^{\prime} 00^{\prime \prime} \mathrm{W}$, at an average altitude of $596 \mathrm{~m}$ and an average slope of $5 \%$.
The climate is classified as "Aw", which refers to tropical climate with summer rains, according to the Köppen classification, and an average annual rainfall of $1,401 \mathrm{~mm}$ and an average temperature of $22^{\circ} \mathrm{C}$ (Rolim \& Aparecido, 2016). Table 1 presents the soil characterizations of the area as a clayey Eutroferric Red Latosol (Embrapa, 2013), according to the soil granulometric analysis by Teixeira et al. (2017).

TABLE 1. Granulometry of the Red Latosol of Santa Clara Farm, Pradópolis-SP (2017).

\begin{tabular}{|c|c|c|c|}
\hline Depth & Clay & Silt & Sand \\
\hline$(\mathrm{m})$ & & $\mathrm{kg}^{-1}$ & \\
\hline $0.00-0.20$ & 695 & 40 & 265 \\
\hline $0.20-0.40$ & 602 & 39 & 359 \\
\hline
\end{tabular}

The study was carried out in a reformed area with soybean crop. It was performed in an area with localized decompression of the soil by a subsoiler acting in the planting line, with a distance of $1.50 \mathrm{~m}$ between shanks and double-winged tips. A heavy-duty disc harrow and a leveling disc harrow were used to incorporate the remaining vegetation and to leave an even and level ground surface, respectively. The systematization process was carried out by the sugarcane mill in order to make the lengths of plots approximately $800 \mathrm{~m}$.

\section{Equipments and inputs}

The harvester used for the experiment was a Case A8800 (2015), with a track-type wheelset, equipped with a Fiat motor $(184 \mathrm{~kW}(250 \mathrm{hp})$ at $1700 \mathrm{rpm})$, and a $1.85 \mathrm{~m}$ control. The same operator controlled the harvester during the harvesting of the seedlings. The amount of straw used was determined by controlling the primary extractor speed (700 or $900 \mathrm{rpm}$ ) at the time of the seedling harvest. Albeit this control, at the time of harvesting seedlings, a visual inspection was conducted on the cleaning of the billets, the settings of the primary extractor were changed from 700 to $900 \mathrm{rpm}$, and the presence of straw in the billets was observed.

A tractor-planter set was used for mechanized sugarcane planting, consisting of a Case IH tractor, Magnum MXM 240, $4 \times 2$ TDA model, with $240 \mathrm{~kW}$ engine power at $2200 \mathrm{rpm}$, six cylinders, 600/65 R28 front wheels, and 710/70 R38 rear wheels. During the mechanized sugarcane planting, the tractor was operated on the 8th working day of March (with the planter and distributor traveling at an average speed of $5.5 \mathrm{~km} \mathrm{~h}-1$ ).

A SERMAG, SMI 10000 was used for mechanized planting of the chopped sugarcane. This model has a twoline, 28-ton capacity for planting seedlings, with two fertilizer deposits having a capacity of $450 \mathrm{~kg}$ each. The planter has furrower shanks spaced at $1.50 \mathrm{~m}$, and the cover is made up of four, 18", smooth and concave discs. The total width of the machine is $3.60 \mathrm{~m}$, and it has two stabilizing and depth regulating wheels of width in the range $0.30-0.45 \mathrm{~m}$.
The distributor, used for the chopped sugarcane, was Antoniosi, DC 6500. This model has a two-line, 4-ton capacity for chopped seedlings, a tank capacity of $650 \mathrm{~L}$ for usage of insecticide, and a pair of scarifying shanks spaced at $1.50 \mathrm{~m}$.

The seedlings used in the planter were the cultivar CTC14, developed by the Centro de Tecnologia Canavieira (CTC), with an average yield of $120 \mathrm{Mg} \mathrm{ha}^{-1}$, a maturity of 125 days, rare flowering, and erect size. At the time of planting, $600 \mathrm{~kg} \mathrm{ha}^{-1}$ of mineral fertilizer with the formulation $10-25-25$ (NPK), $0.250 \mathrm{~kg} \mathrm{ha}^{-1}$ of fipronil insecticide, and $0.50 \mathrm{~L} \mathrm{ha}^{-1}$ were applied with pyraclostrobin fungicide $\left(250 \mathrm{~g} \mathrm{~L}^{-1}\right)$ inside of the furrow.

The semi-mechanized sugarcane planting consisted of the loading (manual cutting) and transport of seedlings; mechanized furrow-fertilization (Valtra tractor, BH180, 4 $\times 2$ TDA with $180 \mathrm{HP}$ ) for furrowing and fertilizer deposition in the soil. The seedling distribution operation was conducted by a Massey Ferguson tractor, 275, $4 \times 2$ TDA, 75 HP. A group of workers split and manually aligned the furrow bottom (using machetes for the total removal of straw attached to the seedlings) and subsequently applied the insecticide to the furrow covers

\section{Data collection and adopted standard}

Data collection was performed in a 50-sample mesh per treatment, with $50 \times 1.50 \mathrm{~m}$ spacing in each plot, making a split block experiment. The five treatments (shown in Table 2) consisted of mechanized strawless planting (MSLP), mechanized straw planting (MSP), mechanized strawless distribution (MSLD), mechanized straw distribution (MSD), and semi-mechanized planting (SMEC). The primary extractor speed determined the presence of straw in the billets; speeds used were 700 and $900 \mathrm{rpm}$.

The implementation of sugarcane plantations using planters is a combined operation (they perform furrowing, distribution, and covering of the seedlings in a single operation), while the distribution of seedlings is only part of the planting operation. There are individualized operations that make up the seedling, planting operations, and semi-mechanized planting (Table 2). 
TABLE 2. Standard established in treatments: their operational characteristics and presence of straw estabelecidos na composição dos tratamentos: suas características operacionais e presença de palha.

\begin{tabular}{lcc}
\hline \multicolumn{1}{c}{ Treatments } & Operations* & Straw in the billets \\
\hline Mechanized strawless planting (MSLP) & Conjugates & Not \\
Mechanized straw planting (MSP) & Conjugates & Yes \\
Mechanized strawless distribution (MSLD) & Separates & Not \\
Mechanized straw distribution (MSD) & Separates & Yes \\
Semi-mechanized Planting (SMEC) & Separates & Not \\
\hline
\end{tabular}

*conjugates: furrowing, distribution and covering in a single operation; separate: furrowing, distribution and covering in individualized operations.

Planting biometric evaluations were performed at the sampling points, consisting of a $10 \mathrm{~m}$ furrow strip. The furrows were reopened for the biometric evaluations of hoe-assisted planting. The reopening was carefully handled, ensuring that no change to the depth of the furrows occurred, as well as no damage or injury to the billet's gems.

\section{Biometric variables of the planting operation}

The biometric planting parameters were performed by removing the soil with the aid of a hoe in two 5-m long furrows parallel to the planting rows. The following biometric parameters were evaluated:

- Number of billets per meter: After planting, the number of billets distributed was counted in the furrows.

- Number of gems in the furrows: the number of total gems contained in the billets (counted in the previous item). This count was obtained by examining each grinding billet individually.

- Number of unviable gems: the count of unviable gems that showed some mechanical damage or attack from any plague; or a visual observation of any factor that could interrupt its sprouting.

- Coverage of furrows: obtained by averaging five measurements at the sample point, using a measuring tape graduated in centimeters, to measure the thickness of the soil layer deposited on the wheels.

- Depth of furrows: Measured using measuring tape arranged vertically within the planting furrow after removal of the soil and grinding wheels from the inside. The measuring tape was positioned in the center of the furrow, i.e., its deepest part, measuring the distance to the level of the natural soil profile. The average of five measurements per sample point was considered.

- Furrow spacing: corresponding to a center-tocenter measurement of the furrows. Five measurements per sampling point were recorded with the aim of verify their parallelism, thus also verifying the efficiency of the self-steering system installed on the tractor.

- Billets length: obtained by averaging 20 grinding wheels randomly collected within the furrow and measuring with a ruler graduated in centimeters.

- Sprouting failures: Planting failure analysis was performed 90 days after the mechanized plant operation (DAP) when sprouting stabilized. This analysis was conducted on the $100-\mathrm{m}$ evaluation plot $(20 \mathrm{~m} \times 5$ rows $)$. The faults were characterized as interruptions in the sprouting lines, higher than $0.50 \mathrm{~m}$ without sprouting within the furrows. Fifty random points were chosen from the planting furrows. The evaluation of sugarcane sprouting failures was based on the methodology proposed by Stolf (1986), i.e., quantifying only the sum of the distance of failures higher than $0.5 \mathrm{~m}$, in relation to the total distance traveled in a sugarcane line (Table 3 ).

TABLE 3. Failure indices for planting quality assessment.

\begin{tabular}{cc}
\hline$\%$ Failure $>0,5 \mathrm{~m}$ & Planting Evaluation \\
\hline $0-10$ & Excellent \\
$11-20$ & Good \\
$21-35$ & Fair \\
$35-50$ & Poor \\
$>50$ & Inadequate \\
\hline
\end{tabular}

Source: Adapted from Stolf (1986).

The focus of the study was to determine the presence of straw in the seedlings through the different planting systems; therefore, the biometric variables of soil cover, furrow spacing, and furrow depth were considered, as these variables may respond to. We used planters and distributors in addition to semi-mechanized planting.

\section{Statistical Process Control}

In order to use the statistical process control (SPC) tools, each repetition was treated as an individual pointto-point value in order to analyze the punctual and existing variability in the operations. In order to construct control boxes for the individual values, all quality indicators of the operation of mechanized sugarcane planting were used, regardless of their assumption of normality (Montgomery, 2016).

The statistical procedures used to define the process stability were the control charts for each variable. The general average as well as the upper (UCL) and lower control limits (LCL) was calculated based on the deviation pattern of the variables (Montgomery, 2016).

The process is considered to be under control or stable when it confirms only random variation, i.e., when the points are between the upper and lower control limits. Thus, when the process is out of control or unstable, the control charts present points above or below the upper and lower control limits, which are observations resulting from special causes extrinsic to the process (Montgomery, 2016).

\section{RESULTS AND DISCUSSION}

According to the control charts for the quantity of the variable gems $\mathrm{m}^{-1}$ (Figure 1a), it was observed that the evaluated processes showed instability in the sample mechanized strawless planting (MSLP) and in semimechanized planting (SMEC), as unstable points were shown during the process. 
According to Montgomery (2016), the instability found in the planting process for the two aforementioned treatments can be linked to one of the $6 \mathrm{Ms}$ factors (i.e., Manpower, Machinery, Materials, Method, MotherNature, Measurement). In this case, since the reduction in the speed of displacement may influence the billet deposition; the workforce influenced the increase in the number of gems per meter in the MSLP, and the SMEC, (verified by means of a visual diagnosis and counting Billets), even after training and working speed guidance at $5 \mathrm{~km} \mathrm{~h}^{-1}$.

The planting process presenting the lowest variability and better stability was found in the MSP, MSLD, and MSD processes, and the average values for the number of gems were similar to those found by Noronha et al. (2011).

The number of viable gems, $\mathrm{m}^{-1}$ (Figure 1b), showed a stable process with all points within the upper and lower control limits for all processes, except for the semi-mechanized process (SMEC). The process instability in semi-mechanized planting is due to machines (accumulation of whole stalks in the area to be planted) and manpower (due to irregular distribution and rationing of whole stalks by rural workers). This treatment is unlike the other treatments, wherein the machines have dosing mats to distribute the billets (gems), which are essential to ensure good results and completion of goals
(Raveli, 2013). An alternative would be to intensify training of tractor operators and farmworkers to align with the expected targets and qualify the workforce (Cortez et al., 2016).

The number of unviable gems (Figure 1c) presents the "out of control" process, albeit the significant data variability due to the absence of straw in the grinding wheels (MSLP, MSLD, and SMEC). Thus, these results indicate that the presence of straw in the billets present greater stability in the planting process and improvement of the quality of the mechanized planting processes (MSP and MSD). The viability of the gems is influenced by mechanized harvesting of seedlings and the friction between gems within the harvester. This is one of the major causes of the increase in the percentage of unviable gems in the planting process (Lai et al., 2011), which in turn increases the requirement of seedlings and the sugarcane implementation cost.

The control chart for billet lengths (Figure 1d) in mechanized harvesting seedling for all processes was kept within the established limits. As the fractionation process of whole stalks was being performed within the planting furrows by manpower (one of the 6Ms factors) in the semi-mechanized operation, the quality of the process presented the highest variability in the length of billets as this process is completed manually using machetes.

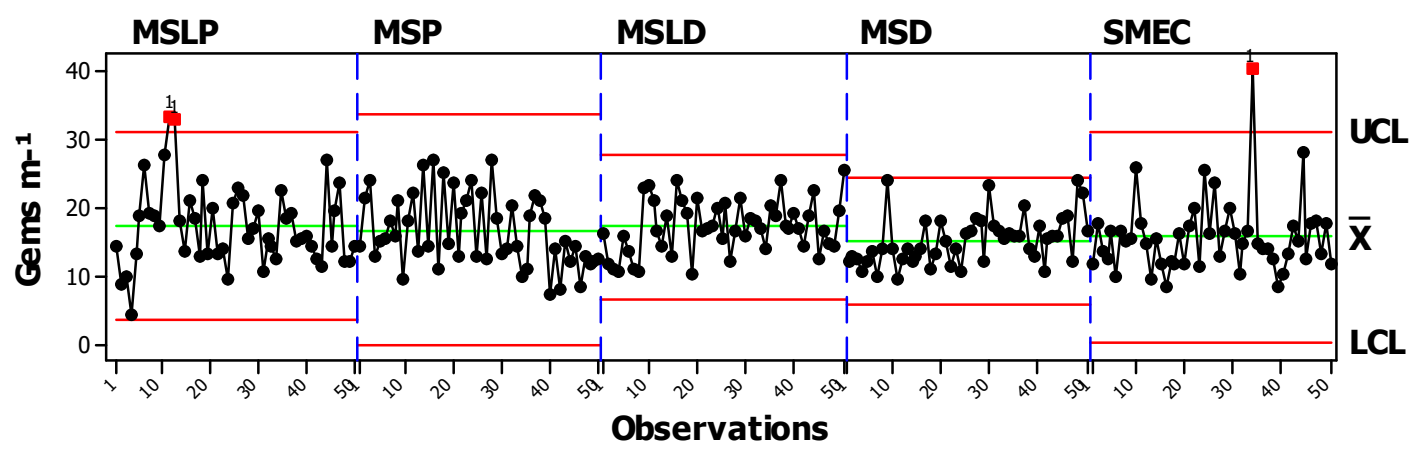

(a)

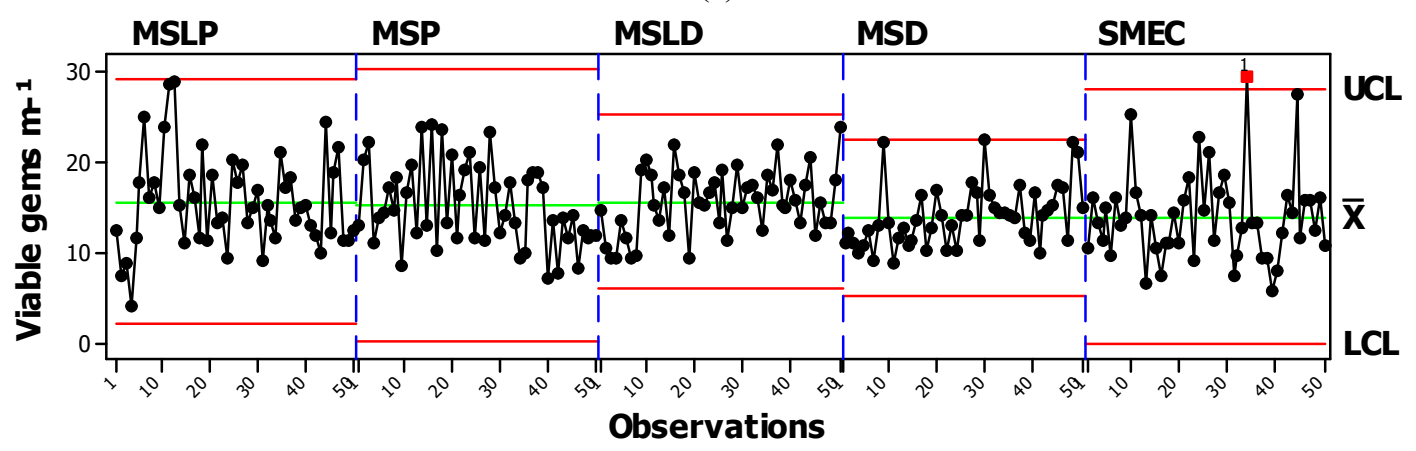

(b)

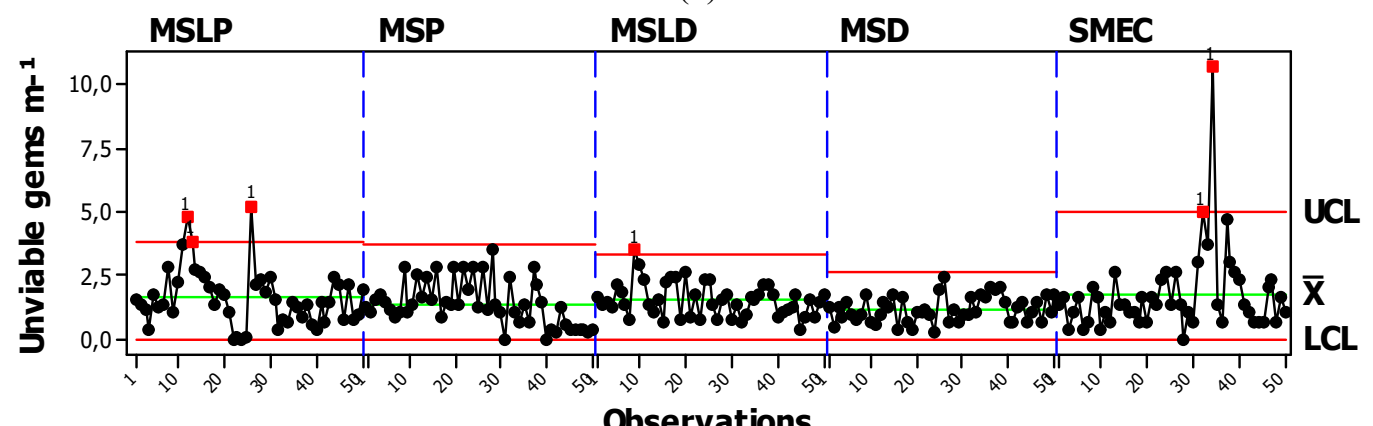

(c) 


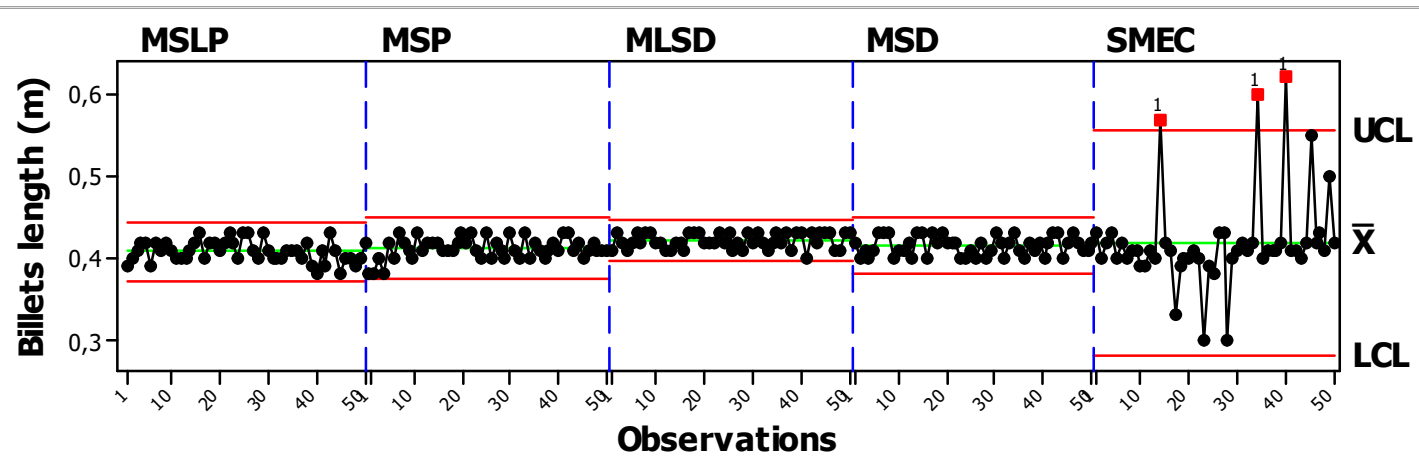

(d)

FIGURE 1. Control charts for the variables for sugarcane planting: number of gems $\mathrm{m}^{-1}$ (a); number of viable gems $\mathrm{m}^{-1}$ (b); number of unviable gems $\mathrm{m}^{-1}(\mathrm{c})$; and billets length $(\mathrm{d})$.

MSLP: mechanized strawless planting; MSP: mechanized straw planting; MSLD: mechanized strawless distribution; MSD: mechanized straw distribution; SMEC: semi-mechanized planting. UCL: upper control limit; LCL: lower control limit; X: average of individual values.

Furrow coverage (Figure 2a) for all processes were stable and within the established standards $(0.05-0.10 \mathrm{~m})$ by the sugarcane processing mills, according to Coleti \& Stupielo (2006) and Voltarelli et al. (2014).

The mean values of furrow depth (Figure $2 b$ ) when the planters were used (simultaneous furrow, distribution, and covering operations in the MSLP and MSP processes), were approximately $5.5 \%$ more superficial than the processes that employed individual operation through the furrowers for opening furrows (MSLD, MSD, and SMEC). This difference shows that a complex mechanism provides greater stability to the planter. However, regarding the furrow opening mechanism - a planter or furrower-used in the planting process, it is noted that the furrow depth remained within the stipulated range for operation between 0.20 and $0.37 \mathrm{~m}$ depth (Voltarelli et al., 2014). These values are within the range observed by Marques \& Pinto (2013), despite the process instability obtained for the
MSLP and SMEC processes. In general, if soil moisture conditions are favorable, reasonable sprouting rates can be obtained, provided they are below $0.40 \mathrm{~m}$ (Compagnon et al., 2017).

The behavior of the points observed in the control charts regarding the furrow spacing (Figure 2c) showed instability in the MSLD process; this was justified by the use of manual planting guidance (manpower factor), which could be avoided/minimized if automatic guidance was employed in the furrow row planting (Baio, 2012). In addition, it is expected that with the alignment of planting furrows, lower trampling indices will occur at harvest time, which consequently increases the longevity of the sugarcane fields. According to Beauclair \& Scarpari (2006), studies show that plantings employing spacing of $1.50 \mathrm{~m}$ have presented operational advantages, minimizing the trampling of sugarcane rows.

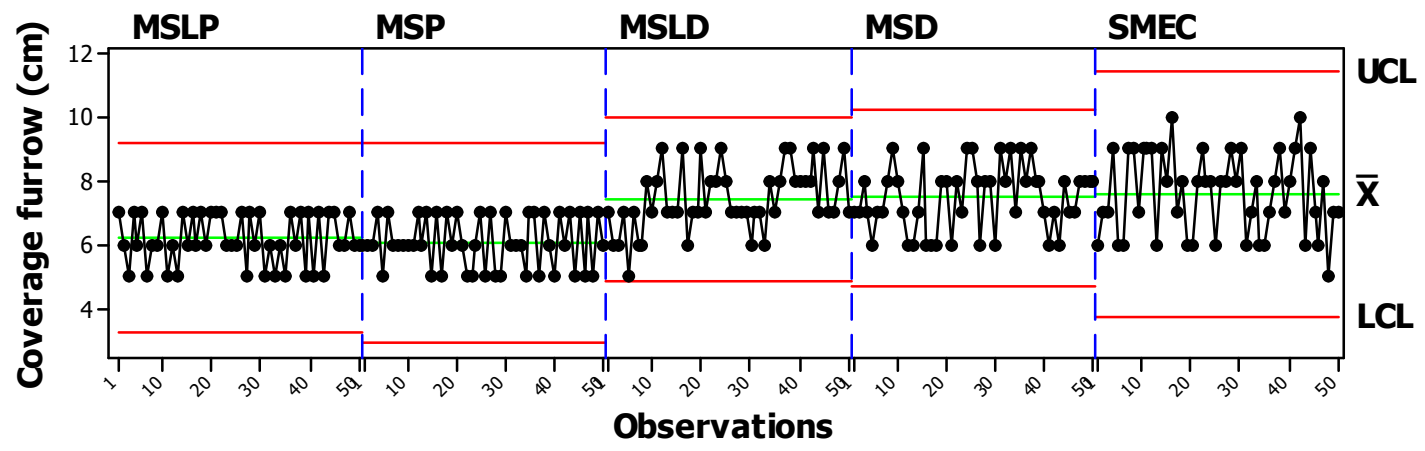

(a)

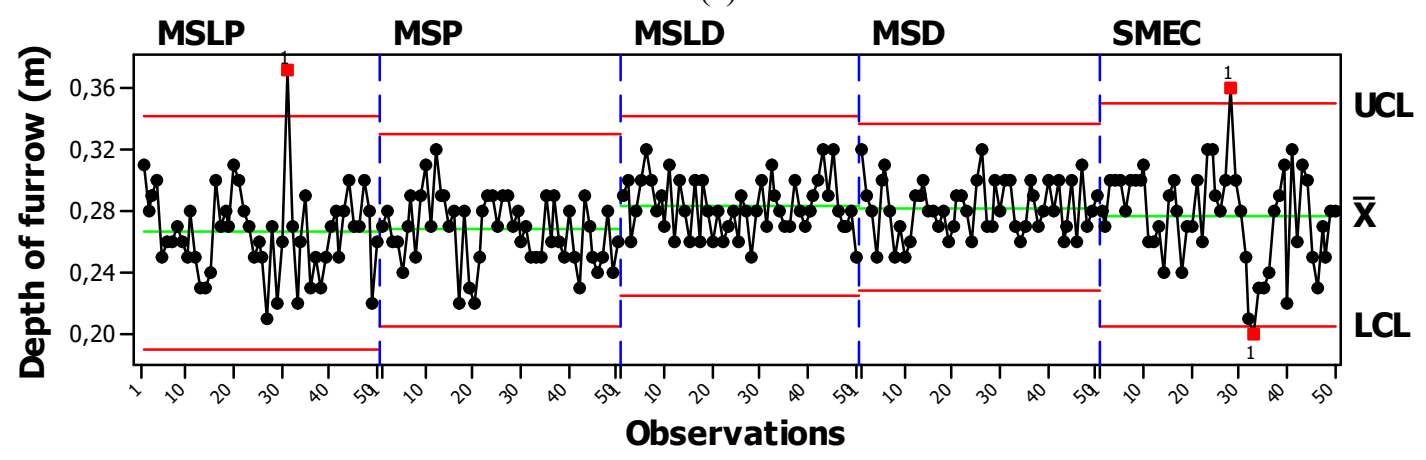

(b) 


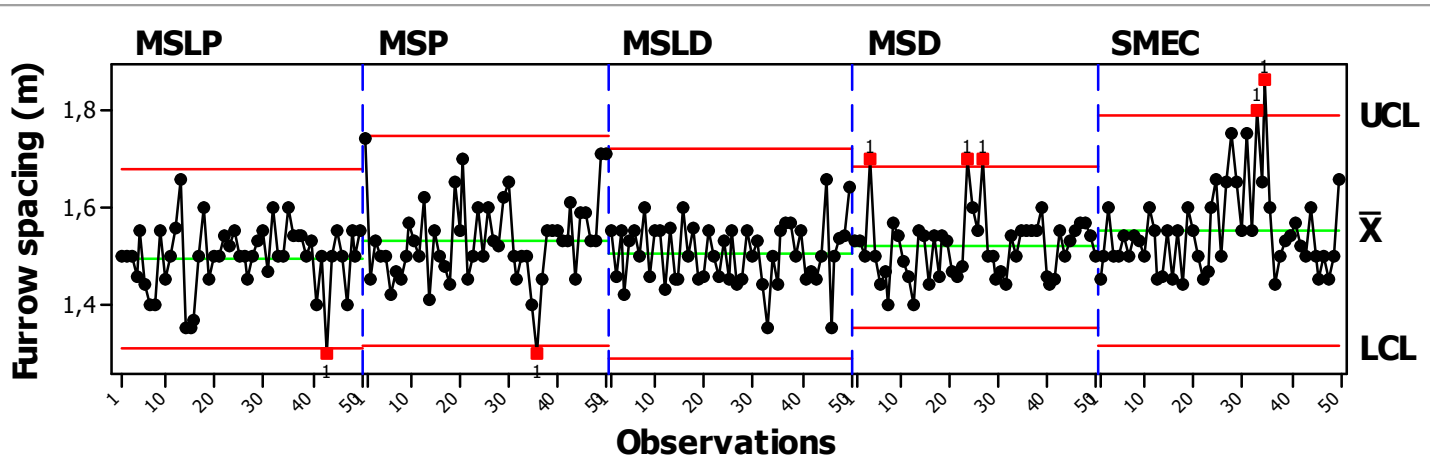

(c)

FIGURE 2. Control charts for operation quality of sugarcane planting: coverage of furrow (a); depth of furrow (b); and furrow spacing (c).

MSLP: mechanized strawless planting; MSP: mechanized straw planting; MSLD: mechanized strawless distribution; MSD: mechanized straw distribution; SMEC: semi-mechanized planting. UCL: upper control limit; LCL: lower control limit; X: means of individual values.

The control chart for the number of stand failures in the period corresponding to stabilization of sprouts, i.e., 90 days after planting (Figure 3), showed an unstable process in the PCSP and SMEC processes, according to Voltarelli et al. (2014), who obtained high data variability for all the processes studied. It is noteworthy that all processes presented relatively lower failure results (below 10\%) than those found by Voltarelli (2014) and Stolf (1986), allowing all studied processes to be classified as acceptable results. Bramley (2009) adopted the same criterion to evaluate the sugarcane stand through images.

Reducing the primary extractor speed to $700 \mathrm{rpm}$ in mechanized harvesting of seedlings through increased retention of straw in billets has improved operational quality in mechanized planting. This process may be used as an alternative strategy for increasing machine-planted areas in October and November, extending the current planting period to five months in the year.

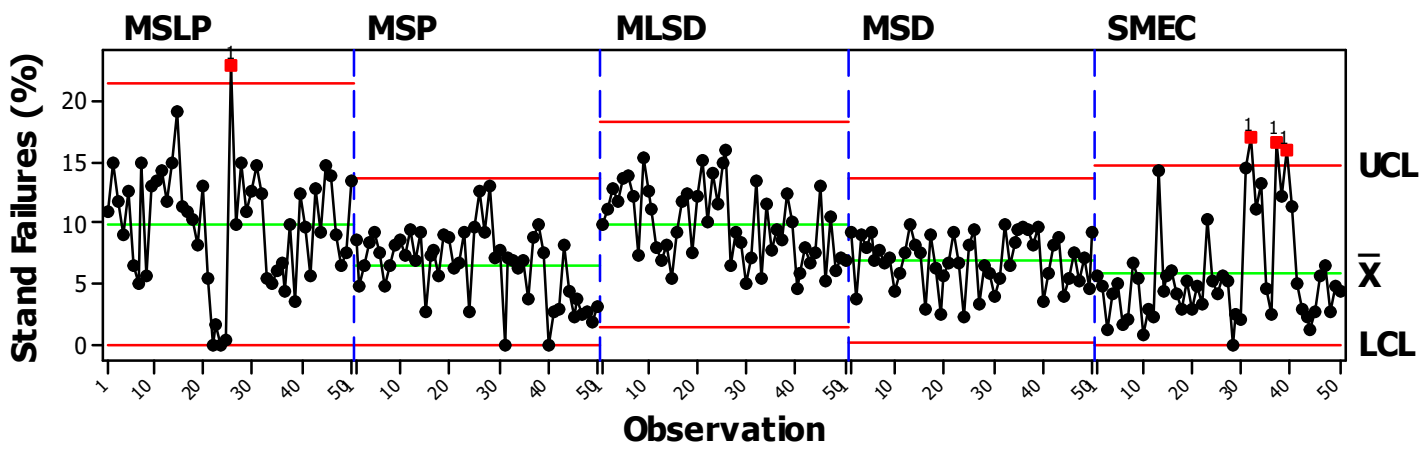

FIGURE 3. Control charts for stand failures at 90 days after planting for operation quality of sugarcane planting.

MSLP: mechanized strawless planting; MSP: mechanized straw planting; MSLD: mechanized strawless distribution; MSD: mechanized straw distribution; SMEC: semi-mechanized planting. UCL: upper control limit; LCL: lower control limit; X: means of individual values.

\section{CONCLUSIONS}

Stand failures were reduced with the presence of straw attached to the billets, providing better protection and viability of gems, thus allowing the potential increase of the planted area.

There were no differences between processes in the variables related to gems and billets length.

The distributor-chopped sugarcane provided greater stability in the depth and furrow coverage data.

Maintenance of straw adhered to the billets has improved the quality of mechanized operations, reducing the number of unviable gems obtained as a result of mechanical damage from the mechanized operation and damage caused by adverse weather conditions.

\section{REFERENCES}

Baio FHR (2012) Evaluation of an auto-guidance system operating on a sugarcane harvester. Precision Agriculture 13(1):141-147. DOI: http://dx.doi.org/10.1007/s11119011-9241-6

Beauclair EGF, Scarpari MS (2006) Noções fitotécnicas. In: Ripoli TCC, Ripoli MLC, Casagrandi DV Plantio de cana-de-açúcar: estado da arte. Piracicaba: Editora Livroceres. p. 80-91.

Bramley RGV (2009) Lessons from nearly 20 years of Precision agriculture research, development, and adoption as a guide to its appropriate application. Crop and Pasture Science 60(3):197-217. DOI: http://dx.doi.org/10.1071/CP08304 
Carlin SD, Silva MA, Perecin D (2004) Fatores que afetam a brotação inicial da cana de açúcar. Revista Ceres 51(296):457-466.

Casagrande AA (1991) Tópicos da morfologia e fisiologia da cana de açúcar. Jaboticabal, FUNEP, 187 p.

Cebim GJ (2008) Plantio mecânico de cana-de-açúcar (Saccharum spp.): desempenho operacional e econômico. Dissertação Mestrado em Engenharia Agrícola, Piracicaba, Universidade de São Paulo, Escola Superior de Agricultura "Luiz de Queiroz".

Coleti JT, Stupielo JJ (2006) Plantio da cana-deaçúcar. Atualização em produção de cana-de-açúcar. Piracicaba: Ed. Prol, v2, p139-153.

Compagnon AM, Silva RP, Furlani CEA, Cavichioli FA, Arriel FH (2017) Operational uniformity for a sugarcane planter. African Journal of Agricultural Research 12(12):953-962. DOI:

http://dx.doi.org/10.5897/AJAR2016.11300

CONAB - Companhia Nacional de Abastecimento (2017) Observatório agrícola acompanhamento da safra brasileira - Cana-de-açúcar. Brasília, 2016. Available: http:

//www.conab.gov.br/OlalaCMS/uploads/arquivos/16_08_1 7 10_07_35_boletim_cana_portugues_-_2o_lev_-_1617.. pdf. Accessed: Oct 23, 2017.

Cortez JW, Missio C, Barreto AKG, Silva MD, Reis GN (2016) Quality of sugarcane mechanized planting. Engenharia Agricola 36(6): 1136-1144. DOI: http://dx.doi.org/10.1590/1809-4430eng.agric.v36n6p1136-1144/2016

Embrapa - Empresa Brasileira de Pesquisa Agropecuária (2013) Centro Nacional de Pesquisa de Solos. Sistema brasileiro de classificação de solos. Embrapa.

Garcia MAL (2008) Avaliação de um sistema de plantio mecanizado de cana-de- açúcar. Dissertação Mestrado em Agronomia, Piracicaba, Universidade de São Paulo, Escola Superior de Agricultura "Luiz de Queiroz".

Ide BY (1984) Cobrimento e seccionamento das mudas de plantio de cana de açúcar. In: Seminário de Tecnologia Agronômica, São Paulo, Coopersucar, Anais...

Lai X, Li S, Ma F, Qin Z, Zhou J, Zheng G (2011)

Simulation and experimental study on sugarcane field excitation to the cutter. Advanced Materials Research 156157:1105-1108. Available:

https://www.scientific.net/AMR.156-157.1105.
Marchiori LFS (2006) Plantio de cana inteira e picada na cana de açúcar. STAB. Açúcar, Álcool e Subprodutos 24(3):28-31.

Marques TA, Pinto LEV (2013) Biomass energy from sugarcane under influence of hydrogel, vegetation cover and planting depth. Revista Brasileira de Engenharia Agrícola e Ambiental 17(6):680-685. DOI: http://dx.doi.org/10.1590/S1415-43662013000600015

Montgomery DC (2016) Introdução ao controle estatístico da qualidade. Rio de Janeiro, Editora LTC, 572 p.

Noronha RHF, Silva RP, Chioderoli CA, Santos EP, Cassia MT (2011) Controle estatístico aplicado ao processo de colheita mecanizada diurna e noturna de canade-açúcar. Bragantia 70:931-938. DOI: http://dx.doi.org/10.1590/S0006-87052011000400028

Raveli MB (2013) Controle de qualidade no plantio de cana-de-açúcar. Dissertação Mestrado, Piracicaba, Universidade de São Paulo, Escola Superior de Agricultura "Luiz de Queiroz".

Rolim GS, Aparecido LEO (2016) Camargo, Köppen and Thornthwaite climate classification systems in defining climatical regions of the state of São Paulo, Brazil. International Journal of Climatology 36(2):636-643. DOI: http://dx.doi.org/10.1002/joc.4372

Stolf R (1986) Metodologia de avaliação de falhas nas linhas de cana-de-açúcar. STAB 4(6):22-36.

Suguisawa JM, Franco FN, Silva SSS, Peche Filho A (2007) Qualidade de aplicação de herbicida em lavoura de trigo. Engenharia Agrícola 27:41-47.

Teixeira PC, Donagemma G, Viana J, Almeida BG, Ruiz H, Klein V, Dechen S, Fernandes R (2017) Análise granulométrica. Rio de Janeiro, Embrapa Solos, 573 p.

Toledo A, Tabile RA, Silva RP, Furlani CEA, Magalhães SC, Costa BO (2008) Caracterização das perdas e distribuição de cobertura vegetal em colheita mecanizada de soja. Engenharia Agrícola 28(4):710-719. DOI: http://dx.doi.org/10.1590/S0100-69162008000400011

Voltarelli MA, Silva RP, Zerbato C, Silva VFA, Cavichioli FA (2014) Agronomic capability of mechanized sugarcane planting. Australian Journal of Crop Science 8:1448-1460. 